\title{
最新の脳卒中リハビリテーション 一運動障害へのアプローチを中心に一
}

\section{三浦聖史下堂薗恵}

\section{要 旨}

脳やシナプスは可塑性を有することが明らかになり，そのメカニズムの解明を背景として，脳卒中リハビリ テーションには, 訓練の量, 頻度ならびに課題特異性という3つの要素が重要であるとの知見が蓄積され, 推奨 されるようになった. 脳卒中急性期では, 早期離床により廃用症候群を予防するとともに, 早期にADL (activities of daily living) を向上させることが重要である. さらに, 回復期ではCI療法 (constraint-induced movement therapy）や促通反復療法といった療法士の指導や徒手による運動療法を軸として, 電気刺激や振動刺激等のさ まざまな物理療法や非侵襲的脳刺激法 (non-invasive brain stimulation：NIBS), リハビリテーションロボット を併用し，患者の運動意図を正しく実現し，反復することが，患者アウトカムを向上させると考えられる．超高 齡社会の我が国における回復期リハビリテーションでは, アウトカム実績とその効率性が求められており, さら に, 近い将来における再生医療の実用化に向け, 効果的かつ効率的なリハビリテーション治療の発展がますます 必要とされるであろう.

〔日内会誌 $108 ： 283 \sim 288 ， 2019]$

Key words 脳卒中, 可塑性, リハビリテーション

\section{はじめに}

近年, 脳卒中リハビリテーションの治療手段 は確実に選択肢が増え, エビデンスも構築され てきている. 古典的な促通手技（Bobath法, Brunnstrom法, PNF (proprioceptive neuromuscular facilitation）法等）が有効との科学的根拠 は乏しく, 麻痺肢に対する訓練の量, 頻度なら びに課題特異性を重視した訓練法が中心とな り，物理療法やリハビリテーションロボットの 併用等あらゆる手段を駆使して学習性不使用 （learned non-use）を予防し，難易度を調整した うえで運動を正しく実現し反復することが重要
であると考えられるようになった。本稿では， 近年の主な脳卒中のリハビリテーション治療に ついて，運動障害へのアプローチを中心に，そ の概要を述べる.

\section{1. 脑の可塑性}

Taubら ${ }^{1)}$ は, 感覚性求心路を遮断されたサル は純粋な運動麻痺がないにもかかわらず, 感覚 麻痺肢を使用しなくなる現象, すなわち, 学習 性不使用を報告した。さらに, Pons ら²) 断された神経路の感覚受容野は隣接する身体部 位の受容野に置き換わることを報告した。リハ 
ビリテーションの治療プログラムにおいて, 麻 痺側上下肢機能の向上を目的とせず，利き手交 換や車椅子使用の訓練のみを優先させるような “ADL自立至上主義”の考え方のもとでは，この 学習性不使用を容易に招き, 回復し得るにもか かわらず，廃用肢に至ってしまう結末になりか ねない. Nudoら ${ }^{3)}$ は, サルの第一次運動野の上 肢の領域に脳梗塞を部分的に作成し，上肢麻痺 を生じさせた後に, 非麻痺側上肢を拘束し, 強 制的に麻痺肢の指を使用させると，手指の麻痺 が改善するとともに，運動野の手指の支配領域 が脳梗塞前の肩の支配領域にまで拡大すること を報告し，脳の可塑性発現のメカニズムが注目 されるようになった。

\section{Cl療法}

CI療法はconstraint-induced movement therapyの略であり, 非麻痺側上肢を三角巾やグ ローブ等で拘束し，麻痺側上肢を強制的に使わ ざるを得ない状況を作り出し，集中的に課題指 向型訓練を行うことで，麻痺側上肢の機能回復 を促す治療法である.Taubらのサルを用いた実 験研究に端を発し, 近年は脳機能画像を用いた 可塑性の証明等，効果を裏付ける研究報告も多 (4). その本質は“拘束”ではなく，“麻痺側上 肢集中訓練”であり,「脳卒中治療ガイドライン 2015」（日本脳卒中学会，2015年）において, グレードAで推奨されている.

しかし，その適応基準として，歩行やセルフ ケアが自立し，患側手関節伸展が随意的に $20^{\circ}$ 以上可能，患側I III指MP関節伸展が随意的に $10^{\circ}$ 以上可能，著明な認知機能低下や高次脳機 能障害がない等の条件を満たす必要があること や，1日あたり 6 時間の訓練を 2 週間に亘り，平 日の 10 日間実施するという診療報酬制度上の ハードルがあることから, 我が国の実臨床で は，エビデンスの高さに比して実施されること が少ないのが現状である。ただし，いかに麻痺
側上肢訓練の量，頻度ならびに課題特異性を確 保し, 患者個々の自主訓練の難易度調整を工夫 するかといった点において, CI療法の考え方は 非常に重要である.

\section{3. 促通反復療法}

促通反復療法は, 鹿児島大学 川平和美名誉 教授が手技を考案・体系化した運動療法であ る. 使用頻度依存的に損傷脳における可塑性が 発現し，それに対応した麻痺肢の回復が得られ ることを理論的背景とし，患者の運動努力のも と，促通手技や注意喚起によって意図した運動 を実現させ，それを高頻度に反復し，大脳皮質 から脊髄前角細胞までの神経路の再建・強化を 効率的に図ることを目標とした治療法である5).

具体的には，治療者による促通刺激，すなわ ち，徒手的な操作や刺激による伸張反射や皮膚 筋反射と，患者自身の運動の意図をタイミング よく同期させる，治療者による「ハイ，伸ばし て!」という聴覚刺激とともに患者自身も患肢 を注視することで，視覚的にも運動の実現を感 覚大力する. 1 つの運動パターンについて, 数 分間で 100 回程度集中反復することで, シナプ スの伝達効率を向上させ, 組織学的結合を強固 にすることで, 新たな神経回路の再建・強化を 目指す（図 1).

促通反復療法の効果は, 運動障害の指標であ るFugl-Meyer assessment（FMA）や物品操作能 力の指標である action research arm test (ARAT) を用いて示されており，回復期ではBrunnstrom ステージIII（共同運動レベル）以上，慢性期で はIV（分離運動の出現）以上で有用性が検証さ れている。促通反復療法は患者の忍容性も高 く, 適応も広い.「脳卒中治療ガイドライン 2015」ではグレードBで推奨されている．随意 性の低い重度麻痺の症例等, 促通反復療法単独 の効果では限界があるケースもあるが, 後述す る神経筋電気刺激との同時併用 ${ }^{6)}$ や, 振動刺激 


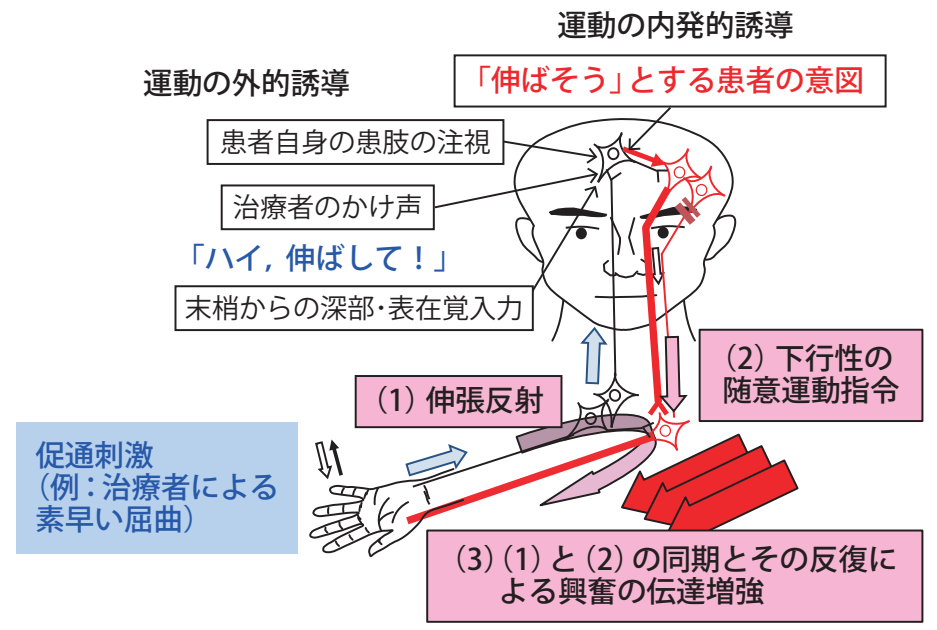

図1 促通反復療法の理論的背景

やボッリヌス療法による痙縮抑制との併用で相 乗効果を期待することもできる.

\section{4. 電気刺激}

電気刺激は，その刺激強度や目的によって， 治療的電気刺激（therapeutic electrical stimulation: TES), 機能的電気刺激 (functional electrical stimulation：FES), 経皮的電気神経刺激（transcutaneous electrical nerve stimulation: TENS) 等 に分類される。詳細は成書に譲るが, 本稿では, 現在，脳卒中片麻痺下肢に対し，ょく使用され ているFESについて述べる.

FESは，中枢神経系の障害で失われた生体の 機能を電気刺激で代行・代償する刺激方法であ る. 特に脳卒中片麻痺に対しては, 中枢からの 運動指令の代わりに制御システムを用いて刺激 を行い，麻痺肢の動作再建を行う。本邦では， NESS L300 ${ }^{\circledR}$ (米国Bioness), ウォークエイド® (帝人ファーマ), NM-F1 ${ }^{\circledR}$ (伊藤超短波) が, 下 肢FESシステムとして承認されている. ウォー クエイド®を例に挙げると, 本システムは表面電 極を下腿の腓骨頭付近に巻き付けるもので, 本 体にバッテリーや傾斜センサーが内蔵されてい
る. 傾斜センサーが患肢の遊脚期を感知し, 総 腓骨神経に電気刺激を加え, 足関節を背屈させ る（図2）。これにより，下垂足を呈する慢性期 脳卒中患者への有効性が報告されており，モー ドが多様で, 早期導入も容易であることが特徴 である7). 我が国においても，多施設共同前向 き比較研究が進行中である.

\section{5. ボツリヌス療法}

Clostridium botulinumによって産生される神 経毒であるA型ボッリヌス毒素は, 未梢の運動 神経の神経筋接合部においてアセチルコリンの 放出を抑制し，筋弛緩作用をもたらす。本邦で は，2010年に「上肢痙縮」及び「下肢痙縮」の 追加効能が承認された。多数の二重盲検ランダ ム化比較試験やsystematic reviewが報告され, 痤縮の評価尺度であるmodified Ashworth scale (MAS) を主要アウトカムとして, その有効性が 証明されている。また, ボッリヌス療法に集中 的リハビリテーションや装具療法を組み合わせ ることで，治療効果の増強・長期化が得られる ことも報告されている8).

標的筋内に直接注射するボツリヌス療法は, 


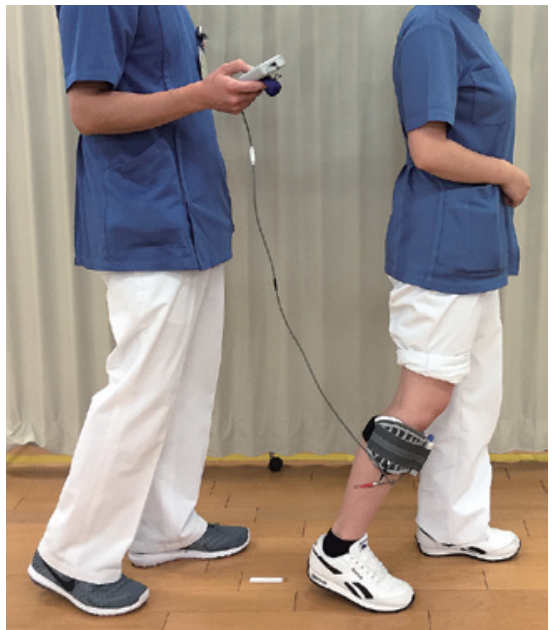

図2 ウォークエイド®の使用風景 （遊脚期における背屈補助）

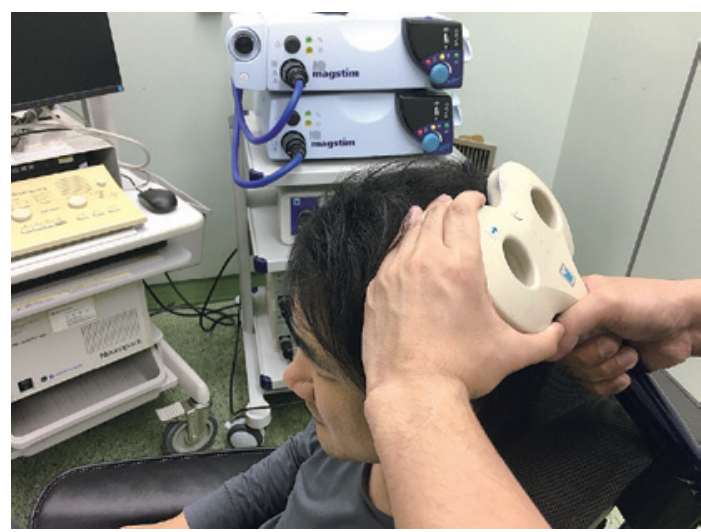

図3 rTMS治療

チザニジン, バクロフェン等の筋弛緩薬内服と 比較して全身作用が少ないことや，フェノー ル，エチルアルコールによる運動点ブロックや 神経ブロックと比較して安全性が高いことが利 点である.一方で, 薬価が高額であるため, 一般 的に回復期病棟入院中の症例での使用は難しい.

\section{6. 非侵襲的脳刺激法 (NIBS)}

現在，非侵襲的脳刺激法（non-invasive brain

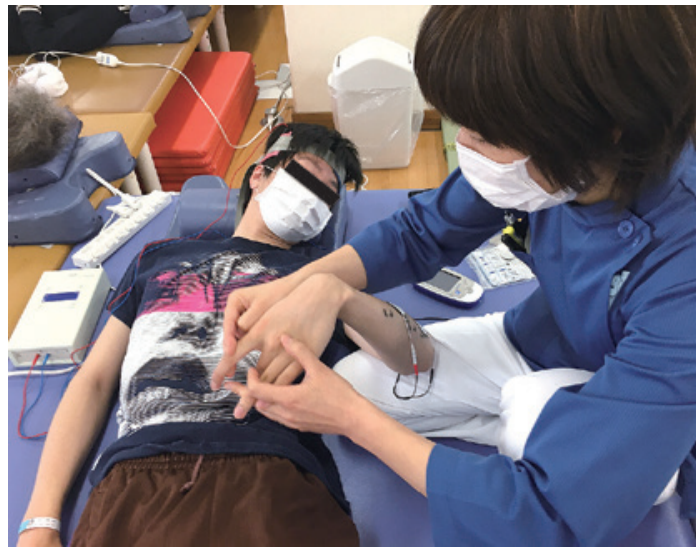

図4 tDCS使用下の促通反復療法

stimulation：NIBS）としては, 経頭蓋磁気刺激 （Transcranial magnetic stimulation : TMS）と経 頭蓋直流電気刺激 (transcranial direct current stimulation：tDCS)が臨床でよく用いられている.

TMSは, 患者の頭部に当てたコイルに電流が 通過し, 高強度の磁場が生成されニューロンを 刺激する方法である（図3)。単発刺激は，一時 的にニューロンを脱分極させるが, 繰り返し刺 激すると, 大脳皮質の興奮性を調節することが できる。これをrepetitive TMS (rTMS) と呼ぶ. 電気生理学的研究に基づく知見では, 低頻度 rTMS（@1 Hz）は刺激された領域内のニューロ ン活動を抑制，高頻度rTMS（ $\geqq 5 \mathrm{~Hz}$ ）は興奮さ せるとされている.

tDCSは, 直流刺激装置と陽極及び陰極刺激電 極からなる，頭皮上に電極を配置し，電極間で 低強度電流を流し, 静止膜電位及びシナプス活 性を調節する刺激方法である（図4）。陽極刺激 は刺激半球の興奮性を増強し, 陰極刺激は抑制 する。

これらNIBSの脳卒中後片麻痺に対する効果 は,「脳卒中治療ガイドライン2015」ではグレー ドC1であり, 刺激条件や刺激部位は一定の見解 を得ていない。一方, 機能回復のためには前述 の促通反復療法との併用 ${ }^{9)}$ をはじめ, 東京慈恵 


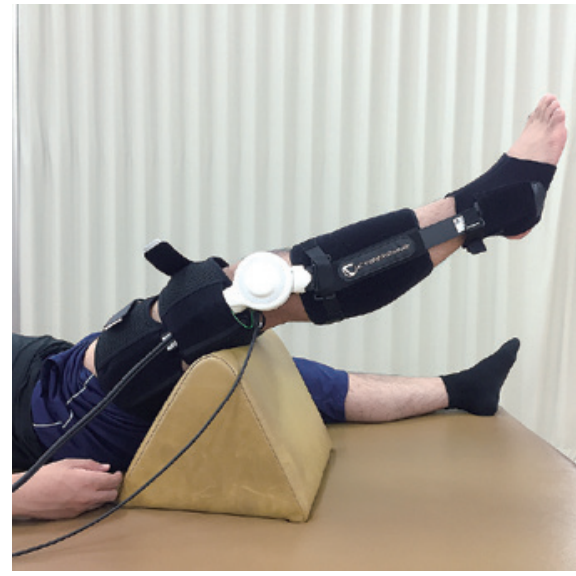

図 5 単関節型 $H A L{ }^{\circledR}$ を用いた膝伸展の訓練

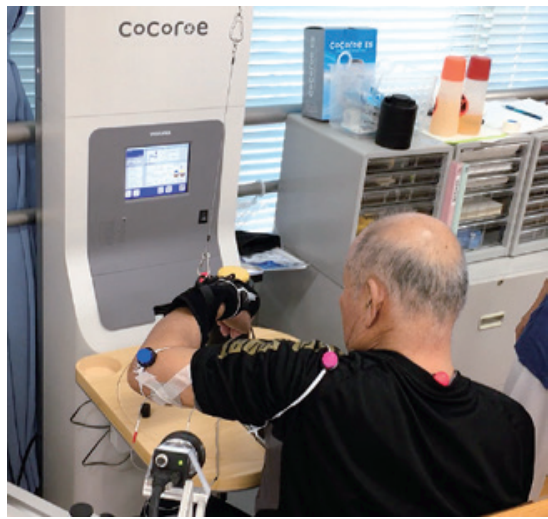

図6 上肢訓練ロボットCoCoroe $\mathrm{AR}^{2}{ }^{\circledR}$ に よるリーチング訓練
会医科大学の研究グループが提唱するNEURO (NovEl Intervention Using RTMS and Intensive Occupational Therapy）等, 集中的な運動療法や 作業療法との併用が重要であり, それらの効果 について多くの研究・報告が蓄積されつつあ る. また, 半側空間無視や注意障害への有効性 の報告もあり，今後のエビデンス蓄積が期待さ れる。

\section{7. ロボットリハビリテーション}

歩行障害に対する歩行補助ロボットを用いた 歩行訓練は, メタアナリシスの結果, 発症3カ 月以内の歩行不能例に使用すると歩行自立の割 合が高く10),「脳卒中治療ガイドライン2015」 でもグレードBで推奨されている.

CYBERDYNE社のHAL (Hybrid Assistive Limb) ${ }^{\circledR}$ は 8つの緩徐進行性の神経・筋疾患で保険収載 された下肢装着型歩行補助ロボットであり，現 在, 脳卒中回復期に対する治験が進行中である.

同社の山海嘉之は, 装置と人を直接接続し, リアルタイムに情報を交換し人を支援する技術 として，サイバニクス（Cybernics）を提唱し， HALはその概念を取り入れた医療機器である. 装着者が運動を意図した際, 皮膚表面に出現す
る生体電位信号を検出し, 歩行運動パターンを 各種センサーから解析し, その随意運動をアシ ストし，装着者と一体となって意図した運動を 実現する.

HALの他には, トヨタと藤田医科大学の共同 開発によるウェルウォークWW-1000 や, Lokomat ${ }^{\oplus}$ ど国内外で多くの歩行補助ロボッ トの研究開発や製品化が進められている.

歩行のみならず，片麻痺上肢への訓練支援口 ボットも多く開発されている。前述のHALには 単関節型もあり, 肘・㯟屈伸の訓練に用いるこ ともできる（図5).ReoGo-J ${ }^{\circledast}$ は, イスラエル Motorika社製ReoGo ${ }^{\circledR}$ を国内プロジェクトで検 証した国内生産品であり, 前向き無作為オープ ン結果遮断試験の結果，回復期での効果が証明 されている.

また, 片麻痺上肢の運動療法として, リーチ ング運動の反復も「脳卒中治療ガイドライン 2015」においてグレードBで推奨されているが, これに麻痺側上肢のスリングによる免荷, 三角 筋 -上腕三頭筋への神経筋電気刺激と振動刺激 を組み合わせた上肢訓練ロボットCoCoroe $\mathrm{AR}^{2 \circledast}$ (安川電機) が市販化されている。難易度調整と して, 免荷量とリーチングの到達点（高さと奥 行き）が可変式であり, さらに, 電気刺激と振 
動刺激による運動促通効果から意図した運動の 効率的な反復を可能としている（図6）.

患者の運動意図を正しく実現し, 反復するこ とは，ニューロリハビリテーションの原則であ り，ロボットリハビリテーションも促通反復療 法等も，ロボットによるか徒手的によるかとい う点は異なるが, 理論的背景は一致していると ころが大きい。

\section{おわりに}

近年の脳卒中リハビリテーションの代表的な
治療法を概説した。医師は早期離床による廃用 症候群予防を徹底したうえで，これらの治療法 の適応や効果を熟知し, 療法士はこれらを武器 として，エビデンスに基づいた治療をチームで 提供しなければならない，再生医療が臨床応用 される将来は近く，効果的かつ効率的なリハビ リテーション治療がますます求められることが 予想される。今後は，これらの治療法相互の併 用療法のエビデンス構築やプロトコール確立等 によって，患者アウトカムのさらなる向上を目 指したい.

著者のCOI（conflicts of interest）開示：下堂薗恵；研究 費・助成金（帝人ファーマ，安川電機）

\section{文献}

1) Taub E : Somatosensory deafferentation research with monkeys : Implications for rehabilitation medicine. Ince LP, ed. Behavioral Psychology in Rehabilitation Medicine : Clinical Applications. Williams \& Wilkins, Baltimore, 1980, 371-401.

2) Pons TP, et al : Massive cortical reorganization after sensory deafferentation in adult Macaques. Science 252 : 1857-1860, 1991

3) Nudo RJ, et al : Neural substrates for the effects of rehabilitative training on motor recovery after ischemic infarct. Science 272 : 1791-1794, 1996.

4) Dong $Y$, et al : Motor cortex activation during treatment may predict therapeutic gains in paretic hand function after stroke. Stroke $37:$ 1552-1555, 2006.

5）川平和美，他：片麻痺回復のための運動療法一促通反復療法「川平法」の理論と実際. 第 3 版，医学書院，2017, $2-10$.

6) Shimodozono $\mathrm{M}$, et al : Repetitive facilitative exercise under continuous electrical stimulation for severe arm impairment after sub-acute stroke : a randomized controlled pilot study. Brain Inj 28 : 203-210, 2014.

7）松元秀次，下堂薗恵：脳卒中 回復期・生活期：ウォークエイド. MEDICAL REHABILITATION 194 : 22-29, 2016.

8) Demetrios $\mathrm{M}$, et al : Multidisciplinary rehabilitation following botulinum toxin and other focal intramuscular treatment for post-stroke spasticity. Cochrane Database Syst Rev (6) : CD009689, 2013.

9) Etoh $S$, et al : Effects of repetitive transcranial magnetic stimulation on repetitive facilitation exercises of the hemiplegic hand in chronic stroke patients. J Rehabil Med 45 : 843-847, 2013.

10) Mehrholz J, et al : Electromechanical-assisted training for walking after stroke. Cochrane Database Syst Rev(7) : CD006185, 2013. 